\title{
Soil nematodes in the field and fallow - density and diversity ${ }^{\star}$
}

\section{Nicienie glebowe na polu i odłogu - zagęszczenie i różnorodność}

\author{
Krassimira Ilieva-Makulec, Renata Franczak, Grzegorz Makulec \\ Institute of Ecology and Bioethics, Cardinal Stefan Wyszyński University in Warsaw, Poland \\ ORCID: KI-M https://orcid.org/0000-0002-7570-3822•k.makulec@uksw.edu.pl
}

\begin{abstract}
The results presented here concern the study, which was carried out in the spring of 2009 on an arable field and a fallow. Following parameters were analysed: density, taxonomic composition, trophic and dominance structure of soil nematode communities. Shannon-Weaver diversity index, Sørensen's index of similarity and Maturity index were also calculated. The results show that the nematode community in the soil of arable field differed from that on the fallow in respect of density and trophic structure. Nematode density was higher in the arable soil than in the fallow. The group of bacterial-feeding nematodes was the most numerous among five trophic groups recorded in the study. The higher density of that group in the arable soil than in the fallow indicates the positive response of bacterial-feeding nematodes to the higher nutrient supply after the manure applying. The results show that in three years of fallow nematode communities became more mature and diverse than in the arable soil. The study confirms the indicative value of some nematode community parameters and indices for the assessment of the varying human intervention on the functional state of the soil.
\end{abstract}

Keywords: soil nematodes, arable field, fallow, biocenotic indices, bioindication

Streszczenie: Przedstawione wyniki dotyczą badań przeprowadzonych wiosną 2009 roku na polu uprawnym i ugorze. Przeanalizowano parametry zespołów nicieni glebowych, takie jak zagęszczenie, skład taksonomiczny, struktura troficzną i struktura dominacji. Obliczono również wskaźniki różnorodności Shannona-Weavera, podobieństwa Sørensena oraz dojrzałości zespołów. Uzyskane wyniki wykazały, że zespoły nicieni w glebie pola uprawnego różniły się od tych na ugorze pod względem zagęszczenia i struktury troficznej. Zagęszczenie nicieni było większe w glebie uprawnej niż na ugorze. Wśród pięciu grup troficznych stwierdzonych w badaniach najliczniejsza była grupa nicieni bakteriożernych. Większe zagęszczenie tej grupy w glebie ornej niż na ugorze świadczy o pozytywnej reakcji nicieni bakteriożernych na zwiększone zasoby pokarmowe po zastosowaniu obornika. Wykazano również, że zespoły nicieni na odłogu, po trzech latach ugorowania, były bardziej dojrzałe i róznorodne niż na polu. Uzyskane wyniki potwierdziły, że wybrane parametry i wskaźniki zespołów nicieni glebowych można z powodzeniem wykorzystywać do oceny stanu środowiska glebowego na terenach przekształconych w wyniku działalności człowieka.

Słowa kluczowe: nicienie glebowe, pole uprawne, odłóg, wskaźniki biocenotyczne, bioindykacja

\section{Introduction}

The intensive development of soil ecology over the last fifty years has contributed to the understanding of the role of edaphone in soil-forming processes and the energy flow and matter circulation. The richness of species of the organisms that inhabit the soil in terms of taxonomy and function reflects its condition. Many scientific works, including Polish ones (Wasilewska 1979; Kozłowska

\footnotetext{
"This article was originally published in Polish as Ilieva-Makulec,Krassimira, Renata Franczak, i Grzegorz Makulec. 2011. "Nicienie glebowe na polu i odłogu - zagęszczenie i różnorodność." Studia Ecologiae et Bioethicae 9(2): 45-66. The translation of the article into English was financed by the Ministry of Science and Higher Education of the Republic of Poland as part of the activities promoting science - Decision No. 676/P-DUN/2019 of 2 April 2019. Translation made by GROY Translations.
} 
1986, 1989; Bongers 1990; Dmowska 1993; Freckman and Ettema 1993; Ferris et al. 1999; Ferris et al. 2001; Dmowska 2002; Yeates 2003; Dmowska and Ilieva-Makulec 2004) proves the possibility of using soil nematodes (microfauna) as an indicator of soil degradation and anthropogenic transformation. In connection with social and economic reforms in Poland after 1989, the areas excluded from agricultural use has increased significantly. In particular, this was due to the setting aside of the State Agricultural Farms (PGR).

According to the Central Statistical Office (2010), the area of waste and fallow land on arable land, which in 1989 amounted to 163,000 ha, w 2002 it reached 2.3 million hectares. In the following years, this area gradually decreased, but after Poland's accession to the EU, a new growth was recorded in both private and public sectors. In accordance with the EU agricultural policy, Poland was obliged to limit the area of arable land. This leads to the search for new, more beneficial ways to manage waste and fallow land. For this purpose, it is necessary to know the changes that take place in the uncultivated former agricultural areas. Research in the field of soil zoology and ecology is one of the key elements to deepen this knowledge. The forming soil faunal communities can show the direction in which the succession of the environment excluded from agricultural use is heading.

The results presented relate to the study conducted in early spring 2009 in two sites, field and fallow, located in the village Dziekanów Leśny.

This study aimed to investigate and compare the density and structure of nematode communities in cultivated and setaside soils, and to evaluate the possibility of using these organisms as an indicator of the condition of the soil environment.

The working hypothesis put forward before the start of the study assumed that succession progressing in set-aside soil would increase the density and diversity of microfauna. It was assumed that leaving the soil undisturbed even after a short period (after 3 years) would promote the development of more mature and complex soil nematode communities.

\section{Material and methods \\ 1.1. Object of the study}

Animals living in the soil are classified using various criteria. The most common classification is the one which takes into account the body diameter of the animals (Swift et al. 1979) and divides them into microfauna, mesofauna, macrofauna and megafauna.

Nematodes (Nematoda) are microscopic animals belonging to soil microfauna, i.e. animals with a body diameter of less than $100 \mu \mathrm{m}$. They are a group distinguished by their very high species richness (Jura 2004). So far, approx. 25,000 nematode species which are widely distributed have been described. In the soil environment, there are approx. 5,000 of them (Wall and Moore 1999). After protozoans, they are the most numerous group in the soil. Depending on the prevailing climatic conditions, soil type, processes taking place in the soil and the way it is used, the distribution, abundance and species composition of the nematodes change (Tischler 1971; Wasilewska 1979). The density of nematodes in different types of environments varies from 60,000 to up to $30,000,000$ of individuals per $\mathrm{m}^{2}$. The most numerous nematodes are found in the soil of grassland ecosystems, while the lowest density of this microfauna group is found in arable soil (Wasilewska 1979).

When assessing the importance of nematodes in soil functioning, both their density and the changes in the mutual relations of individual trophic groups play an important role. Five trophic nematode groups are most commonly distinguished (Yeates et al. 1993):

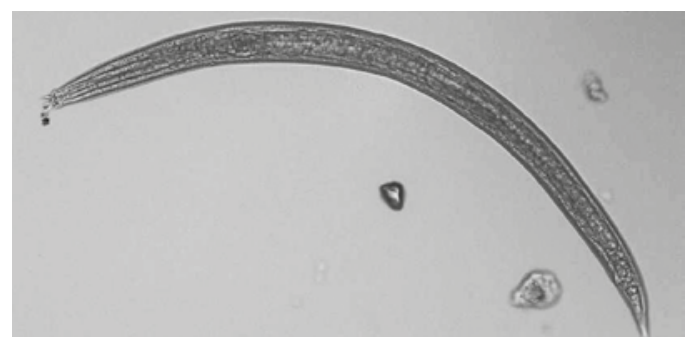

Photo. 1. Bacterial-feeding nematode. (photo: R. Franczak) 
- bacterial-feeding nematodes (Photo. 1) - they feed on bacteria. They are found in all soil types. They account for 30 to $72 \%$ of all nematodes in cultivated soils and coniferous forests, while in grassland ecosystems and deciduous forests, approx. 30\% (Lavelle and Spain 2005). Their density reflects the density of bacteria in the soil. They show selectivity to the species of bacteria that they feed on and require various bacterial densities to develop (Ilieva-Makulec 2001).

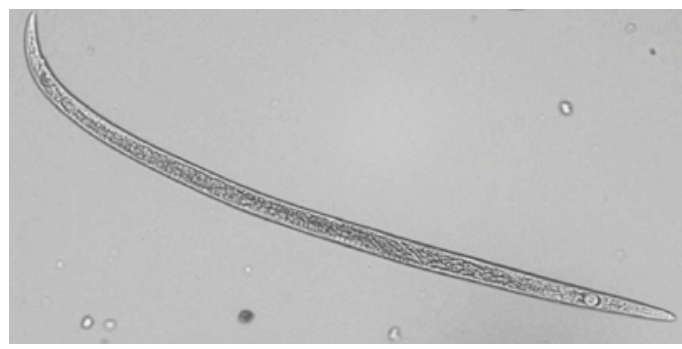

\section{Photo. 2. Fungal-feeding nematode.} (photo: R. Franczak)

- fungal-feeding nematodes (Photo. 2) - they feed on mushrooms by piercing the mycelium with a stylet and sucking out cell juices. They are usually approx. $20-30 \%$ of all nematodes in the soil (Lavelle and Spain 2005). They are most abundant in forest soils, which is associated with a higher density of fungi in forest ecosystems than in farmland and meadows.

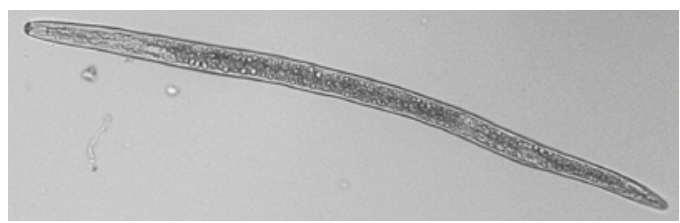

Photo. 3. Plant-parasiting nematode. (photo: R. Franczak)

- plant-feeding nematodes (Photo. 3) - they damage the plant tissues with the stylet located in their mouth cavity. In forest ecosystems, their percentage share varies from 0 to $14 \%$, while in grassland ecosystems and agrocenoses it ranges from 17 to $40 \%$, in some cases even up to 83\% (Lavelle and Spain 2005).

\section{Photo. 5. An omnivorous nematode.} (photo: R. Franczak)

- omnivorous nematodes (Photo. 5) - their digestive system is adapted to a varied diet, which may be fungal hypha, algae, plant cell content or other organisms inhabiting the soil. Their percentage share varies from 5 to $25 \%$, with the highest density in grassland environments (Lavelle and Spain 2005).

Belonging to the trophic group determines the role of the nematodes in the soil environment. Plant-feeding nematodes feeding on roots can lead to the death of 
the entire plant. According to some estimates, the losses in primary production caused by nematodes feeding in grassland ecosystems are 6-13\% (Inghman and Dethling 1984). According to others, they can reach even 28\% (Stanton 1988). In turn, bacterial-feeding and fungal-feeding nematodes play an important post-mineralisation role because they release bioelements (Anderson et al. 1983; Freckman and Caswell 1985) Nematodes from these two groups also affect the composition of microbial communities. By selective choice of their food, they make its composition change. Certain species of bacteria or fungi reduce or increase their abundance.In turn, predators among nematodes are important in the formation of the species composition and abundance of other soil organisms, such as protozoans, rotifers, potworms or even other nematodes (Nielsen quoted from: Burges and Raw 1971).

\subsection{Study area}

The research areas are located in the village Dziekanów Leśny in Mazowieckie Voivodeship, Łomianki municipality, in the buffer zone of Kampinos National Park. Two sites of similar surface area were selected (approx. 0.5 ha). They differed in the ways of use. The distance between the sites was approx. $50 \mathrm{~m}$.

The first research site was arable field (Photo. 6) that is man-made agrocenosis subject to constant agrotechnical treatments. In late autumn 2008, after the harvest, the field area was fertilised with manure and plowed.

The fallow area was the second site (Photo. 7). This was a post-agricultural area that had been excluded from agricultural use three years before. The effect of leaving the land without human intervention is a procedure of secondary succession leading to the restoration of the ecosystem's stability and the natural processes taking place in it (Prończuk 1982).

At both sites, soil samples were collected once in early spring 2009. At the time of sampling, there were no crops in the field, while the plants in the fallow area were at the beginning of the vegetation period.

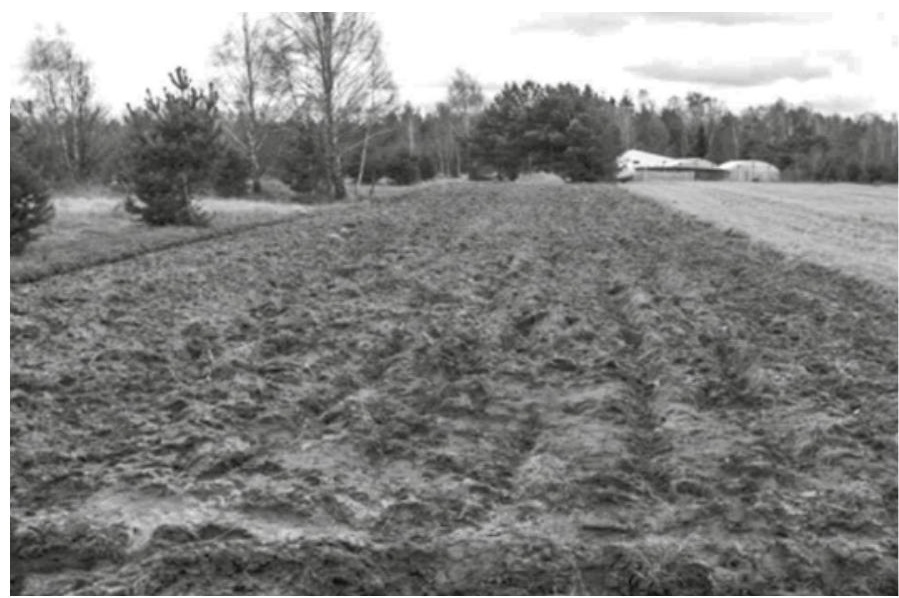

Photo. 6. Arable land. (photo: R. Franczak)

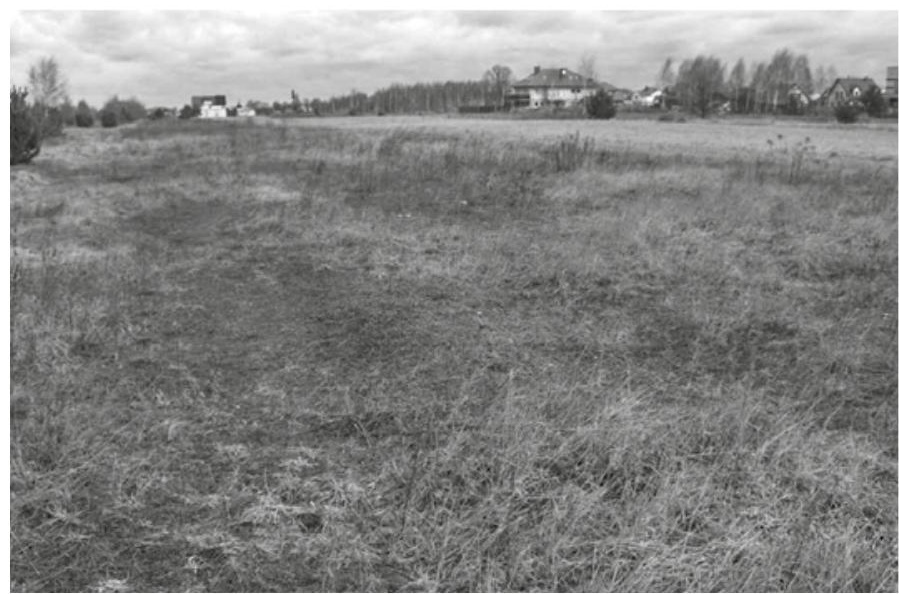

Photo. 7. Fallow land (photo: R. Franczak)

\subsection{Soil sampling, nematode extraction and conservation}

At both sites, in the field and fallow land, 5 soil samples to the depth of $20 \mathrm{~cm}$ each were collected to assess the density and generic composition of microfauna (nematodes). A metal Egner's sampler was used for. The obtained soil samples $\left(2.5 \mathrm{~cm}^{2}\right.$ in area) were divided into two layers: from 0 to $10 \mathrm{~cm}$ and from 10 to $20 \mathrm{~cm}$. In the same way, with the help of an Egner's stick, 3 samples were also collected from two layers of both sites to determine the soil moisture and 1 sample to determine the soil acidity $\left(\mathrm{pH}_{\mathrm{H} 2 \mathrm{O}}\right)$.

In order to extract the nematodes from the soil samples, a modified Baermann's method was applied, using nematode lo- 
comotor activity (Flegg and Hooper 1970). The efficiency of the modified Baermann's method is estimated at approx. $70-80 \%$ (Oostenbrink 1970 quoted from: Górny and Grüm 1981). In this method, nematodes actively pass through a filter to water and then the extracted nematodes are preserved with $4 \%$ formaldehyde.

\subsection{Determination of soil moisture and acidity}

Soil acidity $\left(\mathrm{pH}_{\mathrm{H} 2 \mathrm{O}}\right)$ from both sites was determined using potentiometric method. Soil moisture was assessed using the weighting method in which the difference between the weight of the wet soil sample and its dry weight is given (Mocek et al. 2004). Humidity was calculated according to the formula:

$\frac{\text { wet soil weight-dry soil weight }-d r y \text { soil weight }}{d r y \text { soil weight }- \text { container weight }} \times 100$

\subsection{Nematode parameters under analysis}

The density of nematodes was assessed by counting the extracted animals under a Leica microscope. The results obtained were converted into a unit area $\left[\mathrm{m}^{2}\right]$. In order to identify the fixed organisms taxonomically, individual specimens were transferred to microscope slides using preparation needles. The observations were made under the Leica light microscope. In order to identify nematode genera, Bongers keys were used (1988). Nematode's trophic group was determined according to the classification by Yeates et al. (1993). Five main trophic groups were identified: bacterial-feeding, fungal-feeding, plant-feeding, predatory and omnivorous.

The following biocenotic indicators were calculated:

- The domination ratio was calculated using the following formula (Kasprzak and Niedbała 1981):

$$
\mathrm{D}_{\mathrm{i}}=\mathrm{n}_{\mathrm{i}} \mathrm{N} \times 100 \%
$$

where: $D_{i}$ - domination of the $i$-th species, $\mathrm{n}_{\mathrm{i}}$ - number of individuals of the $\mathrm{i}$-th species, $\mathrm{N}$ - the total abundance of all species.
Four classes of domination were determined: super-dominants - representing more than $30 \%$ of all individuals, dominants - $10-30 \%$, sub-dominants $-2.5-9.9 \%$ and recedents $<2.5 \%$.

- Shannon-Weaver taxonomic diversity index (1949):

$$
H^{\prime}=-\sum_{i=1}^{S} p_{i} \ln p_{i}
$$

where: $\mathrm{S}$ - number of species, $\mathrm{p}_{\mathrm{i}}$ - ratio of the number of individuals of the $i$-th species to the number of individuals of all species: $n_{i} / N$

- Sørensen's taxonomic similarity index (Southwood et al. 2000):

$$
\mathrm{S} \emptyset=2 \mathrm{~s} /\left(\mathrm{s}_{1}+\mathrm{s}_{2}\right) \times 100
$$

where: $\mathrm{s}_{1}$ - number of taxons for set $\mathrm{A}$, $\mathrm{s}_{2}$ - number of taxons for set $\mathrm{B}, \mathrm{s}$ - number of taxons common for set $\mathrm{A}$ and $\mathrm{B}$.

- Maturity index ( $M I)$ developed by Bongers (1990) is used to monitor the conditions and health properties of the soil. Calculation of the index takes into account the life strategy of the taxon and its sensitivity to stress:

$\sum \mathrm{v}_{\mathrm{i}} \mathrm{p}_{\mathrm{i}}$

where: $v_{i}$ - the c-p value for the $i$-th taxon, $\mathrm{p}_{\mathrm{i}}$ - the proportion of the $\mathrm{i}$-th taxon in the whole community.

The value of c-p varies from 1 to 5 and depends on the place of the taxons in the $\mathrm{r}-\mathrm{K}$ strategists continuum (Pianka 1970). Taxons that develop according to $\mathrm{r}$ strategy (colonisers), i.e. fast colonisers, are characterised by high fertility, short maturation time of one generation and tolerance to disturbances are assigned a c-p value equal to 1 . In turn, nematode taxons which behave according to a different strategy K (persisters), i.e. those with long life cycles, poor ability to colonise, a small number of offspring, sensitive to disturbances are assigned to c-p value of 5 . The other 


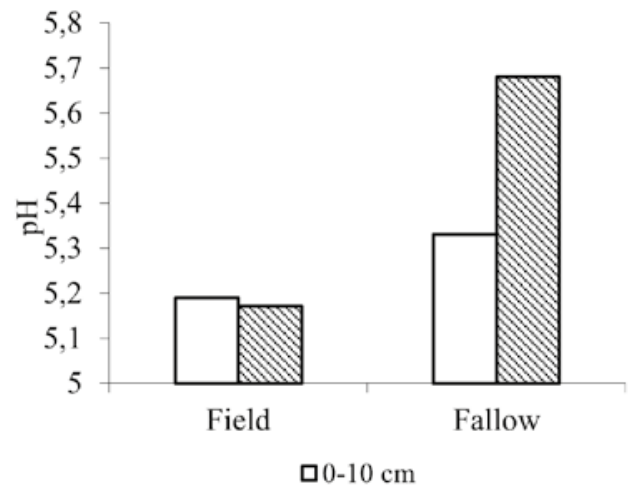

Fig. 1. Soil acidity in the field and fallow land.

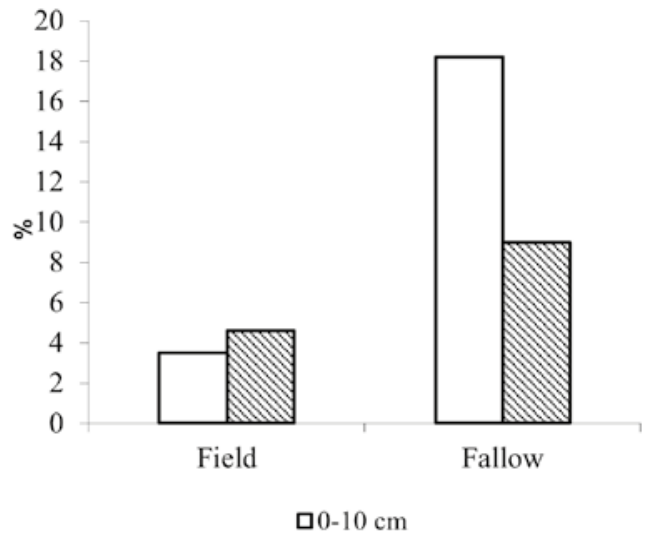

Fig. 2. Soil humidity in the field and fallow land.

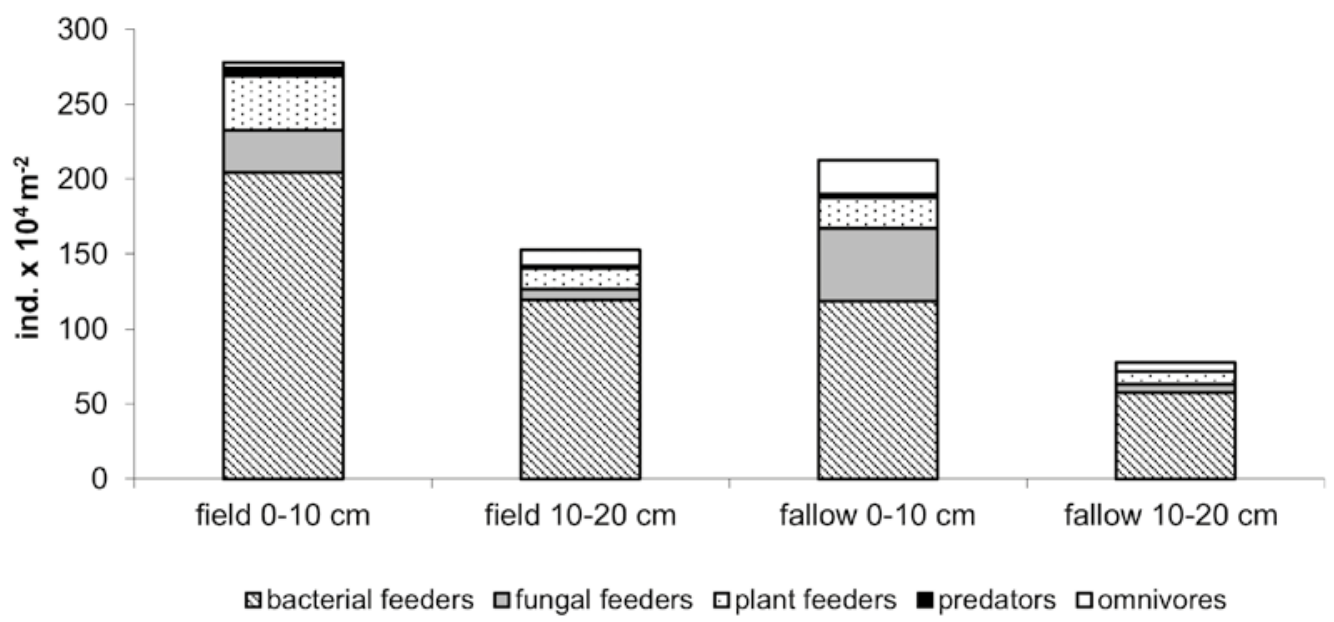

Fig. 3. Average density (total and for trophic groups) of nematodes in the field and fallow in the $0-10 \mathrm{~cm}$ and $10-20 \mathrm{~cm}$ soil layer.

taxons have intermediate positions on the $\mathrm{c}-\mathrm{p}$ scale. The maturity index allows for assessing the condition of the soil environment, the stage of of succession, the degree of disturbance and degradation after various treatments, as well as the process of restoration of the original conditions of degraded soil (Bongers 1990; Freckman and Ettema 1993; Yeates and Bongers 1993; Ferris 1999; Bongers et al. 2001; Yeates 2003; Dmowska and Ilieva-Makulec 2004).

For the analysis of the results concerning nematode density Mann-Whitney's non-parametric U-test was used. The analysis was carried out in Statgraphics programme.

\section{Results}

\subsection{Soil acidity and humidity}

The $\mathrm{pH}$ values (approx. 5.0) indicate that the soil of the cultivated field was acidic, both in the $0-10 \mathrm{~cm}$ and in the $0-20 \mathrm{~cm}$ layer (Fig. 1). In the fallow area, the soil reaction was higher, ranging from 5.3 to $5.7 \mathrm{pH}$. According to the classification by Mock et al. (2004), the soil at this site in the $0-10 \mathrm{~cm}$ layer can be classified as acidic, while in the $10-20 \mathrm{~cm}$ layer it can be classified as slightly acidic.

The weighting method used to determine soil moisture showed that the soil of the arable field was characterised by lower 


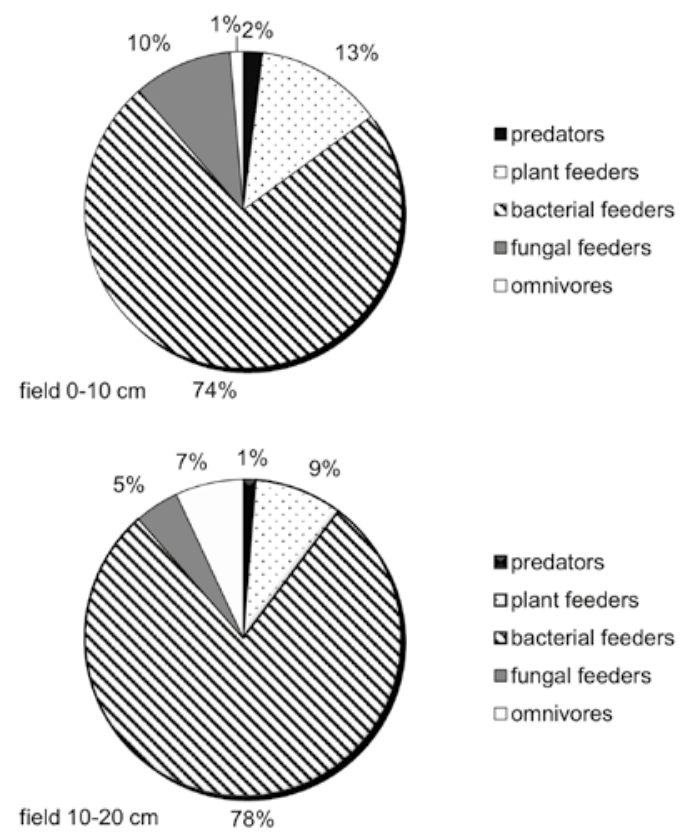

Fig. 4. The percentage share of nematodes in the field in the $0-10 \mathrm{~cm}$ and $10-20 \mathrm{~cm}$ soil layer.

moisture content than that of fallow soil (Fig. 2). The highest water content was found in the top layer of the fallow. $\mathrm{Hu}$ midity in this part amounted to $18 \%$, while in the field it was five times lower - barely $3.5 \%$. Soil moisture in both layers of the field was similar, while soil moisture of fallow land in the deeper layer was twice as low as in the surface layer.

\subsection{Density and trophic structure of nematode communities}

The juxtaposition of the results allowed for concluding that the soils of the field and fallow land differed in terms of microfauna density (Fig. 3). The average density of nematodes in the field was higher than in former farmland in both soil layers. However, only in the $10-20 \mathrm{~cm}$ layer a statistically significant difference was found ( $\mathrm{p}<0.05)$.

In this layer, the average microfauna density in the field was twice as high as in the fallow area. At both sites, the average density of nematodes in surface layers was higher than in deeper soil layers.
Among the extracted nematodes, representatives of 5 trophic groups were identified (Fig. 3). Bacterial-feeding nematodes were the most numerous group. The average density of bacterial-feeding nematodes in the arable soil was significantly higher than the density in the fallow soil in both the $0-10 \mathrm{~cm}$ and $10-20 \mathrm{~cm}$ layer. At both sites, more bacterial-feeding nematodes were found in the $0-10 \mathrm{~cm}$ layer. The percentage share of bacterial-feeding nematodes was high in the trophic structure of nematode communities at both studied sites. They represented over $70 \%$ of the total density (Fig. 4, 5). Only on the surface layer of the fallow soil, their share was lower and amounted to 55\% (Fig. 5).

There were no statistically significant differences in the density of fungal-feeding, plant-feeding and omnivorous nematodes in the cultivated and fallow soil (Fig. 3). Only certain trends were found in the $0-10$ $\mathrm{cm}$ layer. More fungal-feeding and omnivorous nematodes were found in the fallow soil than in the arable soil, and vice versa - more plant-feeding nematodes were recorded in arable soil than in fallow soil.
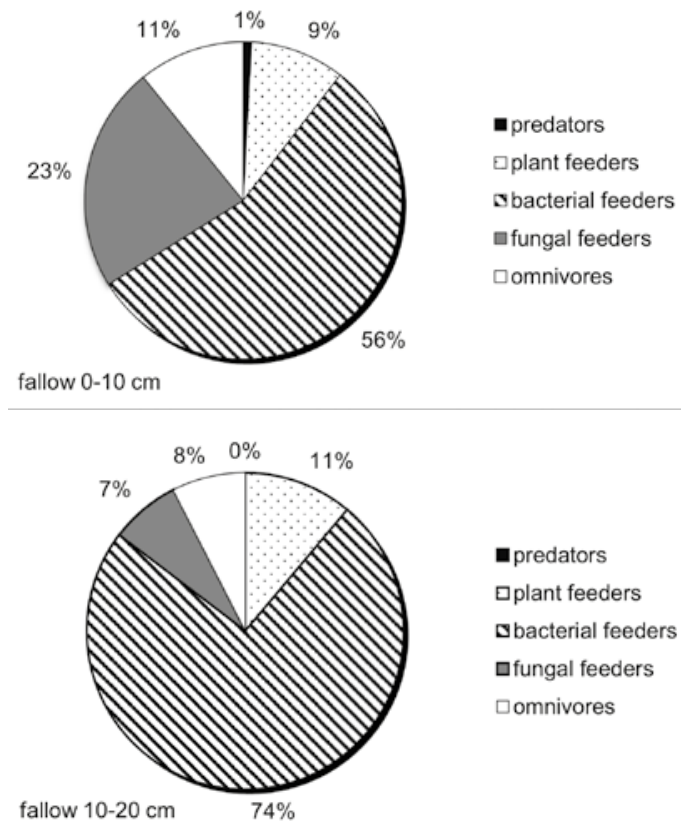

Fig. 5. The percentage share of nematodes in the fallow in the $0-10 \mathrm{~cm}$ and $10-20 \mathrm{~cm}$ soil layer. 
At both sites, fungal-feeding nematodes were more numerous in the $0-10 \mathrm{~cm}$ layer than in the $10-20 \mathrm{~cm}$ layer (Fig. 3). The percentage shares of this trophic group were also significantly higher in the surface layer than in the deeper layer (Fig. 4, 5).

In the field area, the density and percentage share of omnivorous nematodes was higher in the deeper layer (Fig. 3, 4). In the soil of fallow area, however, their density in the $0-10 \mathrm{~cm}$ layer was higher than in the $10-20 \mathrm{~cm}$ layer (Fig. 3). However, the percentage shares of omnivorous nematodes in both layers at this site were similar (Fig. 5).

Predators were the least numerous group (Fig. 3), their insignificant percentage share was marked in the cultivated soil, especially in the top layer (Fig. 4). Not a single representative of this trophic group was found in the fallow soil in the 10-20 cm layer (Fig. 5).

\subsection{Generic composition of nematodes, structure of domination, biocenotic indica- tors of nematode communities}

In total, 28 genera of Nematoda were identified in the soil of the studied environments: Achromadora, Acrobeles,
Acrobeloides, Cephalobus, Cervidellus, Chiloplacus, Eumonhystera, Mesorhabditis, Panagrolaimus, Plectus, Rhabditis, Wilsonema, Aporcelaimellus, Clarkus, Aphelenchoides, Aphelenchus, Ditylenchus, Paraphelenchus, Filenchus, Geocenamus, Helicotylenchus, Meloidogyne, Pratylenchus, Trichodorus, Tylenchorhynchus, Eudorylaimus, Mesodorylaimus and Thonus.

There were 21 of them in the cultivated soil (Fig. 6). In the 0-10 cm layer, the nematode community was represented by 17 genera. Three genera of bacterial-feeding nematodes were dominant: Panagrolaimus, Cephalobus and Plectus. Seven subdominants and seven recedents were found. The least numerous one were omnivorous nematodes of the genus Thonus and bacterial-feeding nemaotdes of genus Chiloplacus. At a depth of 10 to $20 \mathrm{~cm}, 18$ genera were identified, among which also bacterial-feeding ones were dominant: Rhabditis, Acrobeloides and Cephalobus. Six subdominants and nine recedents were found. The least numerous ones in this layer were the nematodes of genera Helicotylenchus and Trichodorus belonging to plant parasiting species.

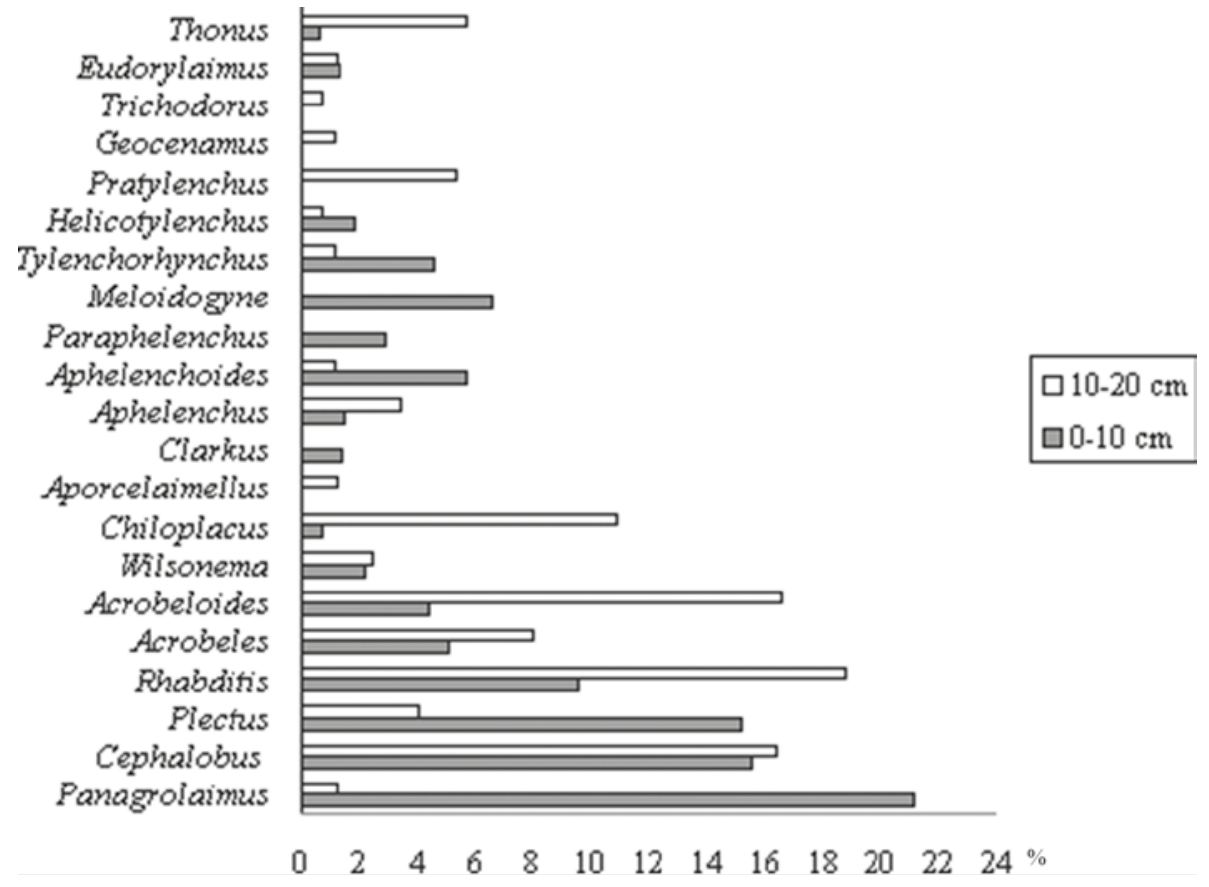

Fig. 6. Structure of nematode genera dominance in arable soil. 
Table 1. Nematode community parameters and indices.

\begin{tabular}{|c|c|c|c|c|}
\hline \multirow[t]{2}{*}{ Parameters and indicators } & \multicolumn{2}{|c|}{ Field } & \multicolumn{2}{|c|}{ Fallow } \\
\hline & $0-10 \mathrm{~cm}$ & $10-20 \mathrm{~cm}$ & $0-10 \mathrm{~cm}$ & $10-20 \mathrm{~cm}$ \\
\hline Number of genera & 17 & 18 & 21 & 14 \\
\hline $\begin{array}{l}\text { Shannon-Weaver } \\
\text { diversity index }\end{array}$ & 2.40 & 2.39 & 2.70 & 1.91 \\
\hline $\begin{array}{l}\text { Sørensen coefficient } \\
\text { of similarity }\end{array}$ & & & & \\
\hline Maturity index (MI) & 1.72 & 1.97 & 2.23 & 2.14 \\
\hline
\end{tabular}

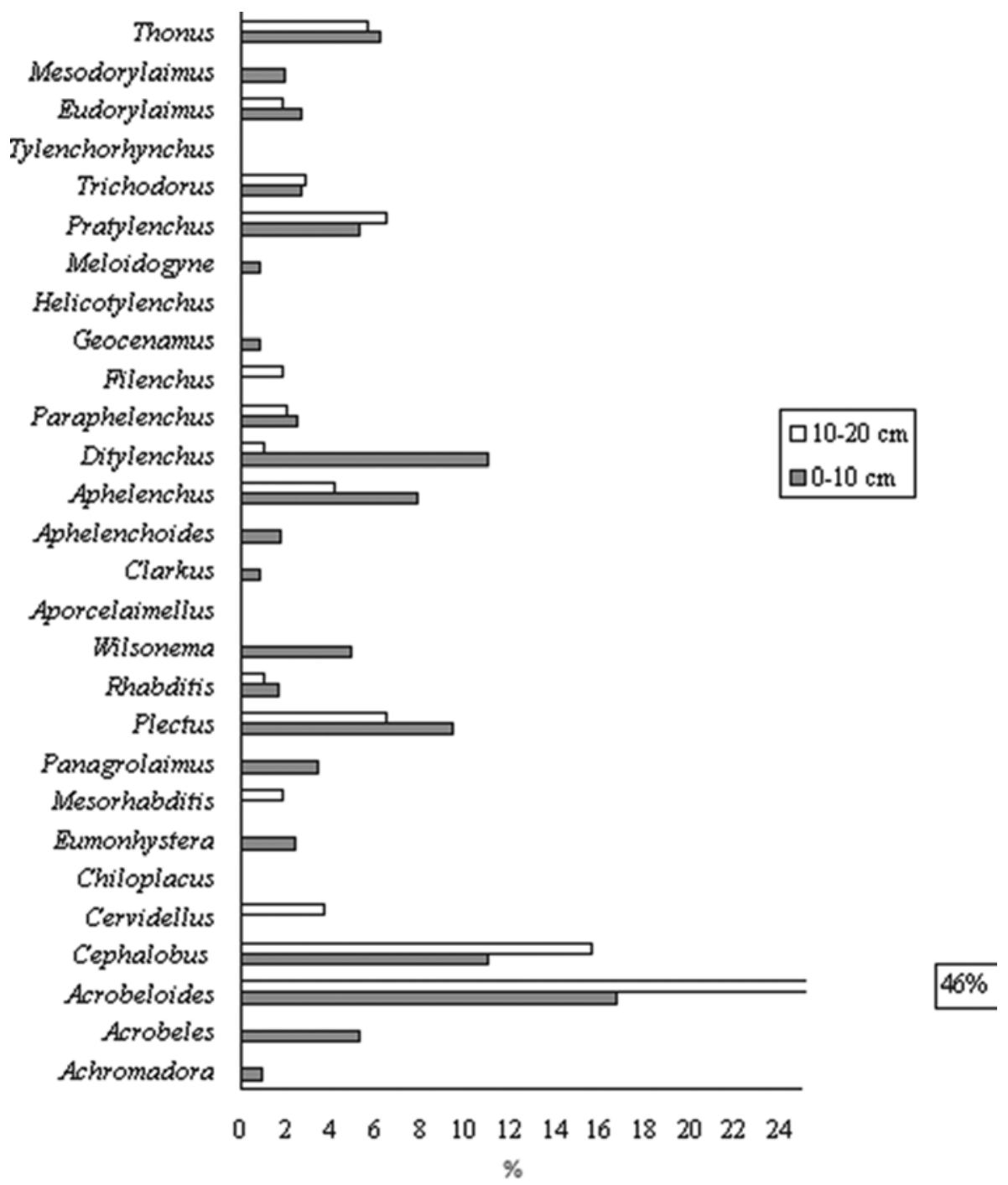

Fig. 7. Structure of nematode genera dominance in set-aside soil. 
The generic composition of the nematodes in both layers of the arable field did not differ. Fourteen genera common to both layers were recorded. The taxonomic similarity index was $80 \%$ (Table 1).

The values of Shannon-Weaver generic diversity index were similar for both depths of the arable field (Table 1).

In the set-aside soil, 24 nematode genera were found, 21 were found in the $0-10 \mathrm{~cm}$ layer and 14 in the deeper layer (Fig. 7). Only 11 genera common to both depths were observed. The Sørensen coefficient was $62 \%$ (Table 1 ).

The top layer of fallow land was dominated by 2 bacterial-feeding nematodes: Acrobeloides and Cephalobus, also by nematodes of the fungal-feeding genus: Ditylenchus (Fig. 7). Nine subdomains and nine recedents were found. In the deeper layer of fallow, the bacterial-feeding nematodes of the genus Acrobeloides clearly prevailed. The percentage share of this genus amounted to almost $46 \%$, which classifies it as a superdominant. Moreover, only 1 dominant was observed in this layer. It was a bacterial-feeding genus Cephalobus. The other genera belonged to sub-dominants (6) and recedents (6).

The values of Shannon-Weaver index for the genera differed in both layers of setaside soil (Table 1). The top layer of fallow land turned out to be much more varied than the deeper layer. Moreover, this layer stood out by the greatest generic diversity among all the examined layers at both sites.

The values of Sørensen coefficient indicate that the generic composition of nematodes in the soil of cultivated field differed from that of the fallow both in the $0-10 \mathrm{~cm}$ layer and in the $10-20 \mathrm{~cm}$ layer. A greater difference was found in the deeper layer where the Sørensen coefficient amounted to only $56 \%$. In the $0-10 \mathrm{~cm}$ layer, the similarity coefficient was $74 \%$. The number of genera common for field and fallow in the $0-10 \mathrm{~cm}$ layer was 14 , while in the $10-20 \mathrm{~cm}$ layer -9 .

The values of the maturity index (MI) of nematode communities were lower for the agricultural soil than for the set-aside soil in both layers, with the difference found in the $10-20 \mathrm{~cm}$ layer than in the $0-10 \mathrm{~cm}$ layer (Table 1).

In the agrocenosis soil, the maturity index was higher in the $10-20 \mathrm{~cm}$ layer than in the $0-10 \mathrm{~cm}$ layer. The reverse situation occurred in the fallow soil - the MI value was higher in the $0-10 \mathrm{~cm}$ layer than in the $10-20 \mathrm{~cm}$ layer. It was also observed that the difference between the MI maturity index values of the examined arable soil layers is greater than the difference between the values of this index for the set-aside soil layers.

\section{Discussion}

The results obtained in this study despite their limitations (soil samples were taken once in spring) indicate that soil nematodes reacted to to the way the land is use. Even after such a short period of time (3 years after the abandonment of agricultural production), the soil nematode communities on the fallow differed from those in the arable land in terms of density, taxonomic composition and functional structure. Both trends, such confirmed by other scientific studies and ones that differ from the results of other studies were found.

The results of numerous scientific works indicate that the density and taxonomic diversity of nematodes is higher in setaside soils than in arable soils (Tischler 1971; Wasilewska 1979; Lavelle and Spain 2005). Such a working hypothesis adopted before the beginning of the research presented here was not fully confirmed.

Nematodes in the present study were more numerous in the arable soil than in the set-aside soil in both layers, $0-10 \mathrm{~cm}$ and 10-20 cm (Fig. 3). This result only seems to contradict the hypothesis at first sight. The higher density of nematodes in the field is mainly due to the higher density of bacterial-feeding nematodes (Fig. $3,4)$. This is a frequent response of this trophic group to increased resources of easily decomposing organic matter as a result of introducing manure into soil. The large food resources in the field are also evidenced by the domination of such genera as Panagrolaimus and Rhabditis (Fig. 6). Nematodes belonging to these genera 
require large food resources to develop their populations (Ilieva-Makulec 2001). The fallow land examined in the study was also dominated by bacterial-feeding nematodes, but their density was lower than in the field soil (Fig. 3, 5, 7). This probably results from a too short period of soil setting aside, during which the accumulated organic matter turned out to be insufficient for the development of nematodes with higher nutritional needs. This is evidenced by the occurrence of one superdominant in the fallow land, which was a generus of very low food demands - Acrobeloides (Fig. 7) (Ilieva-Makulec 2001).

The greater taxonomic diversity of nematodes in the set-aside soil than in the field, and the differences in the taxonomic composition of the communities between the two sites should be explained by the sensitivity of certain microfauna species to ploughing. Mixing of soil layers during ploughing also resulted in the mixing of soil fauna and, consequently, the lack of differences in taxonomic composition of the studied animal groups between the layers $(0-10 \mathrm{~cm}$ and $10-20 \mathrm{~cm})$ in the field compared to fallow.

According to numerous literature data (e.g. Ferris and Ferris 1972; 1974; Popovici 1977; Wasilewska 1974, 1979, 2003) in natural environments, in relation to agrocenoses, there is a predominance of omnivorous nematodes and predators. In this study, despite the lack of significant differences, a similar trend was found for omnivorous and fungal-feeding nematodes (Fig. 3, 4, 5, 6, 7). The lack of significant differences should again be explained by the short time of setting aside. Differences in nematode communities according to the time of setting aside were found by Pate et al. (2000). It seems that the trophic structure of nematodes in the fallow area in this research is just starting to establish. The values of the maturity index also show the progress of succession in the fallow area. Its value is higher in set-aside soil than in arable soil (Table 1). This indicates a higher share of nematode genera with longer life cycles belonging to higher trophic lev- els in the set-aside soil. Even after such a short period of setting aside (only three years), the maturity index turned out to be a very good parameter for estimating the differences in maturity and complexity of the nematode communities between cultivated soil and fallow land. This is also in line with the working hypothesis made at the beginning of the study.

To sum up, the obtained results indicate that the exclusion of soil from agricultural use leads to changes in soil properties, which are reflected in the taxonomic composition and functional structure of soil microfauna communities.

The results confirmed that the parameters and indicators of soil microfauna communities can be successfully used to assess the condition of soil environments subject to different management practices.

\section{Bibliography}

Anderson, Richard V., W. Douglas Gould, Lance E. Woods, Cynthia Cambardella, Russel E. Ingham, and David C. Coleman. 1983. "Organic and inorganic nitrogenous losses by microbivorous nematodes in soil." Oikos 40: 5-80. https://doi.org/10.2307/3544201.

Bongers, Tom. 1988. De Nematoden van Nederland. Utrecht: KNNV Bibliotheekuitgave No 46, Pirola, Schoorl.

Bongers, Tom. 1990. "The maturity index: an ecological measure of environmental disturbance based on nematode species composition." Oecologia 83: 14-19. https://doi. org/10.1007/BF00324627.

Burges, Alan, and Frank Raw. 1971. Biologia gleby. Warszawa: PWRiL.

Dmowska, Ewa. 1993. "Effects of long-term artificial acid rain on species range and diversity of soil nematodes." European Journal of Soil Biology 29: 97-107.

Dmowska, Ewa. 2002. „Rola pierwotniaków i nicieni w środowisku glebowym." Wiadomości Ekologiczne 48(4): 267-278.

Dmowska, Ewa, and Krassimira Ilieva-Makulec. 2004. "Past and present status of nematode community indicators." Nematology Monographs and Perspectives 2: 487-501.

Ferris, Virginia R., and John M. Ferris. 1972. "Nematode community dynamics in natural 
and disturbed environments." Proceeding of XI International Symposium of Nematologists, 21-22. Reading: University of Reading.

Ferris, Virginia R., and John M. Ferris. 1974. "Inter-relationships between nematode and plant communities in agricultural ecosystems." Agro-Ecosystems 1: 275-299.

Ferris, Howard, Tom Bongers, and Ron G.M. de Goede. 1999. "Nematode faunal indicators of soil food web condition." Journal of Nematology 31: 534-535.

Ferris, Howard, Tom Bongers, and Ron G.M. de Goede. 2001. "A framework for soil food web diagnostics: extension of the nematode faunal analysis concept." Applied Soil Ecology 18: 13-19.

Flegg, Jim J. M., and David J. Hooper. 1970. "Extraction of free-living stages from soil." Technical Bulletin Ministry of Agriculture, Fisheries and Food 2: 5-22.

Freckman, Diana W., and Edward P. Caswell. 1985. "The ecology of nematodes in agroecosystems." Annual Review Phytopathology 23: 275-296.

Freckman, Diana W., and Christien H. Ettema. 1993. "Assessing nematode communities in agroecosystems of varying human intervention." Agriculture, Ecosystems and Environment 45: 239-261. https://doi. org/10.1016/0167-8809(93)90074-Y.

Górny, Mieczysław, and Grum Leszek. 1981. Metody stosowane $w$ zoologii gleby. Warszawa: PWN.

Ilieva-Makulec, Krassimira. 2001. "A comparative study of the life strategies of two bacterialfeeding nematodes under laboratory conditions. II. Influence of the initial food level on the population dynamics of Acrobeloides nanus (de Man 1880) Anderson 1968 and Dolichorhabditis dolichura (Schneider 1866) Andrassy 1983." Polish Journal of Ecology 49: 123-135

Ingham, Russell E., and James Detling. 1984. "Plant herbivore interactions in a North American mixedgrass prairie. III. Soil nematode populations and root biomass on $C y$ nomys ludovicianus colonies and adjacent uncolonized areas." Oecologia 63: 307-313.

Jura, Czesław. 2004. Bezkręgowce. Warszawa: Wydawnictwo Naukowe PWN.

Kasprzak, Krzysztof, and Wojciech Niedbała. 1981. „Wskaźniki biocenotyczne stosowane przy porządkowaniu i analizie danych w badaniach ilościowych." W Metody stosowane w zoologii gleby, red. Mieczysław Gorny, and Leszek Grum, 397-408. Warszawa: Wydawnictwo Naukowe PWN.

Kozłowska, Jadwiga. 1986. "Communities of soil nematodes in grassland ecosystems periodically flooded with pig liquid manure." Polish Ecological Studies 12: 137-145.

Kozłowska, Jadwiga. 1989. "The effect of sewage sediments on communities of soil nematodes." Polish Ecological Studies 15: 27-39.

Lavelle, Patrick, and Alister V. Spain. 2005. Soil ecology. Dordrecht: Springer.

Mocek, Andrzej, Stanisław Drzymała, and Piotr Maszner. 2004. Geneza, analiza $i$ klasyfikacja gleb. Poznań: Akademia Rolnicza.

Pate, Emmanuelle, N. Ndiaye-Faye, Jean Thioulouse, Cécile Villenave, Tom Bongers, Patrice Cadet, and D. Debouzie. 2000. "Successional trends in the characteristics of soil nematode communities in cropped and fallow lands in Senegal (Sonkorong)." Applied Soil Ecology 14: 5-15.

Pianka, Eric R. 1970. “On r- and K-selection.” American Naturalist 104: 592-597.

Popovici, Iuliana. 1977. "The specific structure and affinity of nematode populations in brown-humus soil and leached chernozem." Pedobiologia 17: 216-221.

Prończuk, Józef. 1982. Podstawy ekologii rolniczej. Warszawa: Wydawnictwo Naukowe PWN.

Shannon, Claude E., and Warren Weaver. 1949. The mathematical theory of communication. Urbana: Unversity of Illinois Press.

Southwood, Thomas R.E., and Peter A. Henderson. 2000. Ecological methods. London: Blackwell Science Ltd.

Stanton, Nancy L. 1988. "The underground in grasslands." Annual Review of Ecology and Systematics 19: 573-589.

Swift, Michael J., O. William Heal, and Jonathan M. Anderson. 1979. Decomposition in terrestrial ecosystems. Berkeley: University of California Press.

Tischler, Wolfgang. 1971. Agroekologia. Warszawa: PWRiL.

Wall, Diana H., and John C. Moore. 1999. "Interactions Underground. Soil biodiversity, mutualism, and ecosystem processes." BioScience 49(2): 109-117. 
Wasilewska, Lucyna. 1974. "Analysis of a sheep pasture ecosystem in the Pieniny Mountains (The Carpatians). XIII. Quantitative distribution, respiratory metabolism and some suggestion on production of nematodes." Ekologia polska 22: 651-668.

Wasilewska, Lucyna. 1979. „The structure and function of soil nematode communities in natural ecosystems and agrocenoses." Polish Ecological Studies 5: 97-145.

Wasilewska, Lucyna. 2003. „Wpływ uproszczenia zbiorowisk roślinności łąkowej na biologię gleby i procesy rozkładu materii. Bioindykacyjna rola fauny glebowej." Kosmos 52(2-3): 357-364.

Yeates, Gregor W., Tom Bongers, Ron G.M. de Goede, Diana W. Freckman, and Slavka S. Georgieva. 1993. "Feeding habits in nematode families and genera - an outline for soil ecologists." Journal of Nematology 25: 315-331.

Yeates, Gregor W. 2003. "Nematodes as soil indicators: functional and biodiversity aspects." Biology and Fertility of Soils 37: 199-210. https://doi.org/10.1007/s00374-003-0586-5. 